\title{
Reworked late Neogene Austrochlamys anderssoni (Mollusca: Bivalvia) from northern James Ross Island, Antarctica
}

\author{
D. PIRRIE ${ }^{1}$, H.A. JONKERS ${ }^{2}$, J.L. SMELLIE ${ }^{3}$, J.A. CRAME ${ }^{\mathbf{4}}$ and J.M. MCARTHUR ${ }^{\mathbf{5}}$ \\ ${ }^{1}$ Helford Geoscience LLP, Menallack Farm, Treverva, Penryn, Cornwall TR10 9BP, UK \\ ${ }^{2}$ Dommerswijk 10, 7782 PA De Krim, The Netherlands \\ ${ }^{3}$ Department of Geology, University of Leicester, University Road, Leicester LE1 7RH, UK \\ ${ }^{4}$ British Antarctic Survey, NERC, High Cross, Madingley Road, Cambridge CB3 OET, UK \\ ${ }^{5}$ Department of Geological Sciences, University College London, Gower Street, London WC1E 6BT, UK \\ dpirrie@helfordgeoscience.co.uk
}

\begin{abstract}
We report on the discovery of a new outcrop of fossiliferous Neogene sediments on northern James Ross Island, northern Antarctic Peninsula. Approximately 100 specimens of the pectinid bivalve Austrochlamys anderssoni (Hennig, 1911) were collected from the permafrost active layer. This bivalve species has a late Miocene to late Pliocene range and has previously been reported from both the glaciomarine Hobbs Glacier Formation and the interglacial Cockburn Island Formation in the James Ross Island area. The localized presence of abundant $A$. anderssoni within the permafrost suggests that the fossils have been frost heaved from an outcrop of either the Cockburn Island or the Hobbs Glacier formations, originally deposited on northern James Ross Island. The overall shell form, general absence of associated Antarctic Peninsula-derived clasts in the host sediment, and the measured ${ }^{87} \mathrm{Sr} /{ }^{86} \mathrm{Sr}$ isotope ratio of the shells (0.709050) which is indistinguishable from that for pectinid bivalves from the Cockburn Island Formation on Cockburn Island (0.709047) suggest that the shells were derived from a unit similar in age to the Cockburn Island Formation. This suggests that the Cockburn Island Formation was originally more laterally extensive than was previously known.
\end{abstract}

Received 26 January 2004, accepted 8 September 2010, first published online 26 January 2011

Key words: Cockburn Island Formation, fossil reworking, Hobbs Glacier Formation, late MiocenePliocene, permafrost

\section{Introduction}

Although the James Ross Basin is well known for its extensive Cretaceous and early Tertiary sedimentary record, there are also important small, isolated exposures of late Miocene to Pliocene sedimentary rocks associated with the James Ross Island Volcanic Group (e.g. Sykes 1989, Pirrie et al. 1997, Jonkers et al. 2002, Smellie et al. 2006, Hambrey et al. 2008, Nelson et al. 2009). Together with the volcanic rocks, these sedimentary rocks and their associated fauna provide important palaeoenvironmental data for the northern Antarctic Peninsula region during the late Miocene and Pliocene epochs (e.g. Smellie et al. 2006, 2008, 2009, Nelson et al. 2008, Williams et al. 2010). One important component of the fauna associated with these sedimentary rocks are pectinid bivalves, first described from Cockburn Island by Andersson (1906). These bivalves, which are assigned to Austrochlamys anderssoni, were originally thought to indicate interglacial conditions but have also been described from glaciomarine strata (Jonkers et al. 2002). In this paper the presence of reworked Austrochlamys anderssoni in modern day periglacial sediments on northern James Ross Island is described. The occurrence of these bivalves is interpreted as reflecting periglacial reworking of late
Miocene to late Pliocene sedimentary units initially deposited on northern James Ross Island. Fossiliferous Neogene outcrops are uncommon in the region, and in Antarctica generally, but the discovery of the Brandy Bay outcrop is evidence that these fossiliferous outcrops are more widely distributed than was once thought. They are a potentially rich, but as yet underutilized, resource of past climatic and palaeoenvironmental conditions (e.g. Williams et al. 2010).

\section{Field setting and stratigraphy}

Abundant specimens of Austrochlamys anderssoni were collected from a $30 \mathrm{~m}^{2}$ area of modern periglacial active

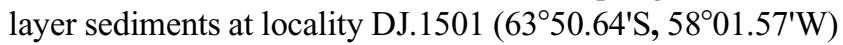
south-west of San Carlos Point, Brandy Bay, northern James Ross Island at an altitude of c. $75 \mathrm{~m}$ (Fig. 1). The geomorphological setting is a low-gradient slope with well developed patterned ground (Bibby 1965, Lundqvist et al. 1995, Björck et al. 1996). Bibby (1965) recognized a number of such low-gradient terrace-like surfaces around James Ross Island and interpreted them in terms of marine erosion surfaces (cf. Strelin \& Malagnino 1992). The bivalve specimens were vertically to sub-vertically oriented within 


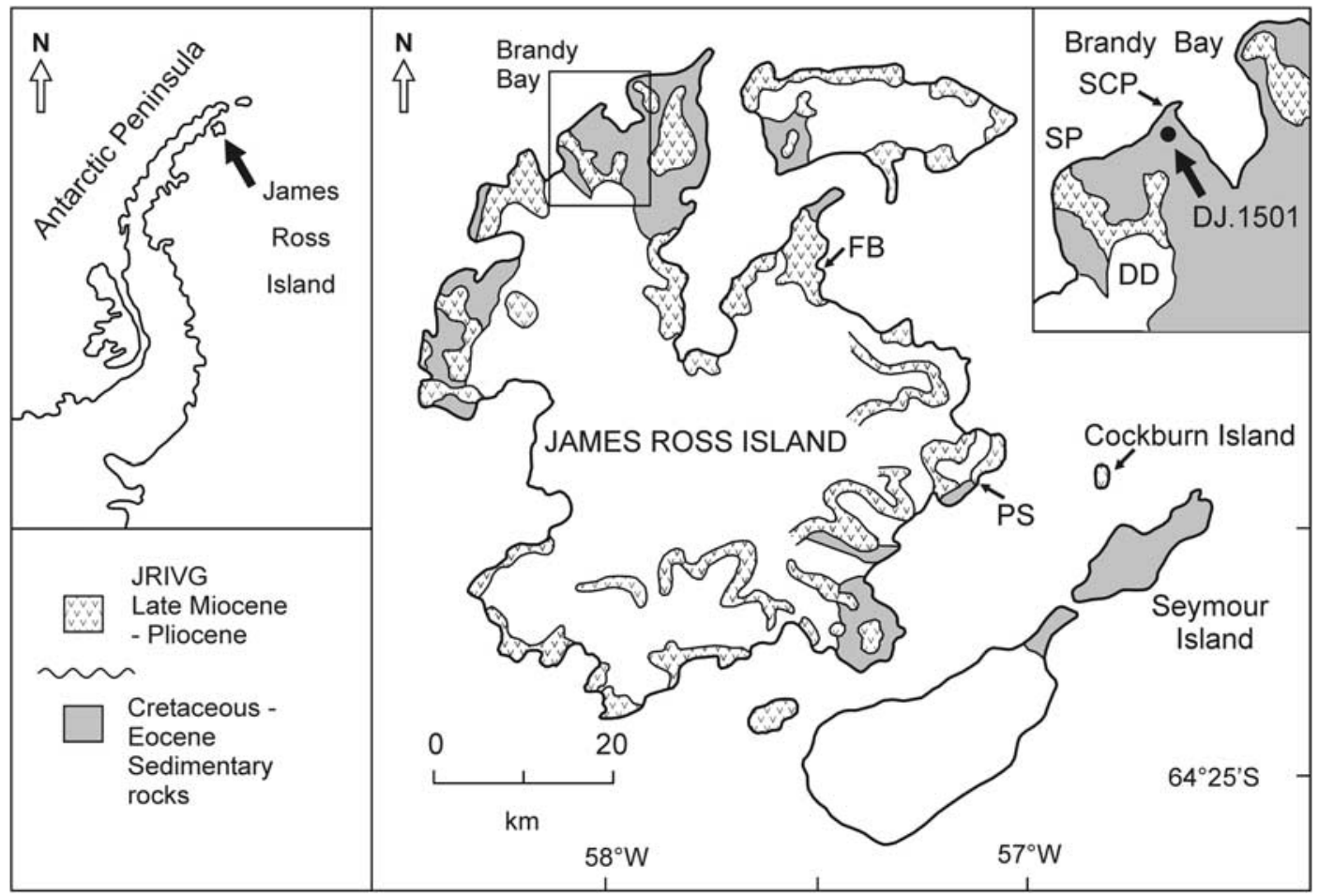

Fig. 1. Sketch geological map of James Ross Island. Previously documented localities where Austrochlamys anderssoni has been collected are highlighted. $\mathrm{FB}=$ fiorda Belén, $\mathrm{PS}=$ Pecten Spur, $\mathrm{SCP}=$ San Carlos Point, $\mathrm{SP}=\mathrm{Stoneley} \mathrm{Point,} \mathrm{DD}=\mathrm{Davis}$ Dome.

the active layer sediments (Fig. 2) and, commonly, concentrated within fractures defining the patterned ground. The thin-shelled bivalves are disarticulated, but show little abrasion. Larger clasts within the active layer sediments at the sample site are mainly basaltic rock fragments derived from the James Ross Island Volcanic Group, along with clasts of granite and metasedimentary rocks comparable with Trinity Peninsula Group lithologies exposed in the northern Antarctic Peninsula region (cf. Pirrie et al. 1997, Smellie et al. 2006, Nelson et al. 2009). Clasts interpreted as derived from the Trinity Peninsula Group also occur throughout the underlying Cretaceous sedimentary succession on James Ross Island (Ineson 1989, Pirrie 1991), together with rare granitic clasts. Both clast types are present within the late Miocene to Pliocene glacial sedimentary units associated with the James Ross Island Volcanic Group (Pirrie et al. 1997). However, clasts reworked from the Cretaceous strata on James Ross Island are typically rounded or well rounded and can usually be easily distinguished from the characteristically angular clasts derived directly from the Antarctic Peninsula (Smellie et al. 2006, Hambrey et al. 2008, Nelson et al. 2009).

Austrochlamys anderssoni has previously been described from both the late Pliocene Cockburn Island Formation (Jonkers 1998a) and from a number of late Miocene to possibly late Pliocene sedimentary units associated with the James Ross Island Volcanic Group (Smellie et al. 2006, Nelson et al. 2009, Williams et al. 2010). The Hobbs Glacier Formation was originally described from southern
James Ross Island where it is late Miocene in age, unconformably overlies Cretaceous sedimentary units and in turn is overlain by the James Ross Island Volcanic Group (Pirrie et al. 1997). In its type area, the formation is a laterally extensive, but thin (few to several metres), diamictite-dominated unit which was sourced from the Antarctic Peninsula, along with clasts derived from older or even potentially contemporaneous parts of the James Ross Island Volcanic Group (Pirrie et al. 1997). Subsequently, Jonkers et al. (2002), Smellie et al. (2006), Hambrey et al. (2008) and Nelson et al. (2009) described the presence of sedimentary rocks (mainly diamictites and conglomeratic sediment gravity flow deposits) interbedded with the James Ross Island Volcanic Group from numerous localities on James Ross Island. These exposures are late Miocene to late Pliocene in age (Smellie et al. 2006, Nelson et al. 2009) and Jonkers et al. (2002) suggested that they should be included within the Hobbs Glacier Formation, a practice we also adopt here for convenience of description only. Thicknesses of $64-150 \mathrm{~m}$ are reached in a few outcrops, and many of the stratigraphically higher deposits interbedded with the volcanic units on James Ross Island lack Peninsuladerived erratics (Nelson et al. 2009, Smellie et al. 2009).

The Cockburn Island Formation, defined by Jonkers (1998a), is only known to crop out on Cockburn Island. The formation comprises sandstones, pebbly sandstones and conglomerates, which overlie volcanic rocks of the James Ross Island Volcanic Group. It has yielded a molluscan 


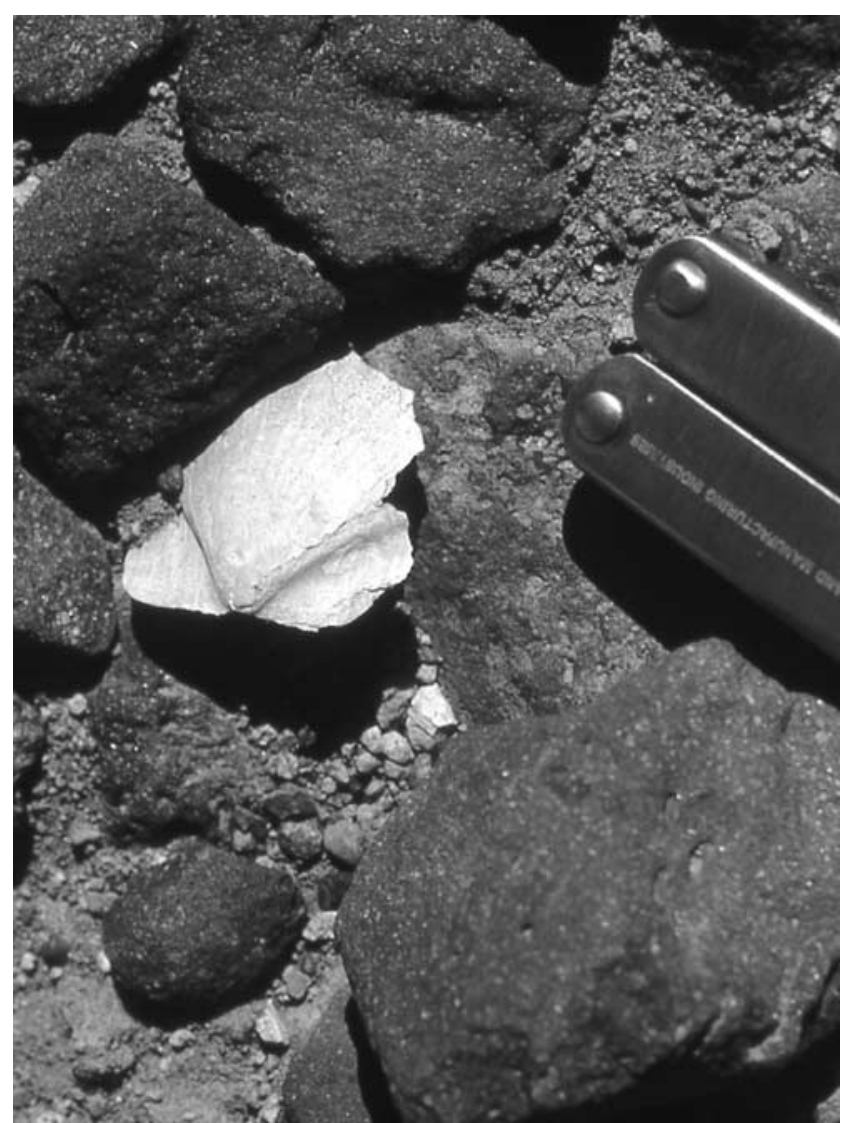

Fig. 2. Field photograph showing a sub-vertically aligned specimen of Austrochlamys anderssoni within the surface sediments. Coarse grained clasts surrounding the bivalve are basalts derived from the James Ross Island Volcanic Group. Width of "leatherman" tool is $3 \mathrm{~cm}$.

fauna including very abundant specimens of Austrochlamys anderssoni, along with the bivalves Adamussium colbecki cockburnensis Jonkers, 2003, Laternula elliptica (King \& Broderip, 1832), and a species of Hiatella (DJ.854.39; HAJ previously unpublished information), and the gastropods Nacella concinna (Strebel, 1908), and Trophon sp. Other macrofossils include the barnacle Fosterella hennigi Newman, 1979, brachiopods, a cidarid echinoid (Jonkers 1998a) and an extensive assemblage of encrusting bryozoans (U. Hara, personal communication 2003). A similar biota also occurs in fossiliferous outcrops of the Hobbs Glacier
Formation (Jonkers et al. 2002, Williams et al. 2010). The Cockburn Island Formation has been interpreted as reflecting a transition from a rocky shoreline environment down to water depths of approximately $100 \mathrm{~m}$ (Jonkers 1998a). An essentially sea ice-free setting was also inferred principally based on a virtual absence of ice-rafted debris derived from the Antarctic Peninsula, which contrasts with many of the outcrops of the Hobbs Glacier Formation (Jonkers 1998a, see also Jonkers \& Kelley 1998). Dating of the Cockburn Island Formation was initially controversial, with a mean $\mathrm{Sr}$ isotope date reported in Dingle et al. (1997) of 4.7 Ma (+0.6/-1.2), based on the V3:10/99 look-up table of Howarth and McArthur (1997), being in conflict with an age, based on diatom biostratigraphy, that is close to $3 \mathrm{Ma}$ (Jonkers \& Kelley 1998). ${ }^{40} \mathrm{Ar} /{ }^{39} \mathrm{Ar}$ dating of one of the lavas underlying the Cockburn Island Formation yielded an age of c. 4.8 Ma, providing a maximum age for the formation (Jonkers \& Kelley 1998). A depositional age of $4.66(+0.17 /-0.24) \mathrm{Ma}$ (indistinguishable from that suggested by Dingle et al. 1997) was established by McArthur et al. (2006), based on further $\mathrm{Sr}$ isotopic analyses of multiple pectinid shells.

There are several sedimentary outcrops associated with the James Ross Island Volcanic Group relatively close to the fossil locality reported herein. These sedimentary rocks occur in, and at the base of, the volcanic cliffs on the north side of Davis Dome (Fig. 1) and they also form a large outlier of sedimentary rock, at least $20 \mathrm{~m}$ thick and $500 \mathrm{~m}$ in extent, situated near (east of) Stoneley Point (Smellie et al. 2006, 2008). Four volcanic units have been distinguished in the James Ross Island Volcanic Group at Davis Dome. The oldest (at Stoneley Point) is a tuff cone remnant whilst the younger units represent different phases of effusion as lavafed deltas (Skilling 2002, Smellie 2006). A single thick volcanic delta formed of lava and hyaloclastite breccia unit dominates the outcrop (Smellie et al. 2008). Discontinuous sedimentary beds typically $1-1.5 \mathrm{~m}$ thick separate each of the volcanic phases, but the deposits thicken to 10 and $18 \mathrm{~m}$ at two places. Most are dominated by massive to crudely bedded, pale grey to dark brown diamictite with abundant silty to fine sandy matrix (typically $60-70 \%$ ), and granules to boulders of basalt derived from the James Ross Island Volcanic Group, less common hyaloclastite breccia and a distinctive but minor population (few \%) of quartz-veined phyllite and fine sandstone, granitoids, and altered intermediate to evolved lavas derived from the Antarctic

Fig. 3. Austrochlamys anderssoni, from a. Cockburn Island, and b-e. Brandy Bay, James Ross Island. a. DJ.851.2, almost complete right valve (topotype; VH $114.5 \mathrm{~mm}$; UA $107^{\circ}$, UAA $55^{\circ}$, UAP $52^{\circ}$ ). b. DJ.1501.11, dorsal part of disc with hinge of right valve (computed valve height $106.4 \mathrm{~mm}$ ). c. DJ.1501.18, dorsal part of disc with hinge of left valve (computed valve height 102.7 mm). d. DJ.1501.54, internal view of median part of right valve, showing medioventral part of disc outside pallial line and foliated calcite re-entry with part of adductor muscle scar (top right) and gill suspensor scars (valve height unknown). e. Right valve, reconstructed from DJ.1501.8/8a (ventral and posterior part of disc with posterior auricle, originally one specimen; VH $114.1 \mathrm{~mm}$ ), DJ. 1501.3 (dorsal part of disc with hinge, largely hidden from view; computed valve height $101.2 \mathrm{~mm}$ ), and DJ.1501.27 (anterior part of disc, valve height unknown). All specimens illustrated at natural size, coated with ammonium chloride. DJ.851.2 collected by H.A. Jonkers \& S.L. White, 18 January 1996; all other specimens collected by D. Pirrie \& J.A. Crame, 9 January 2002. Specimens are kept in the BAS collections. 


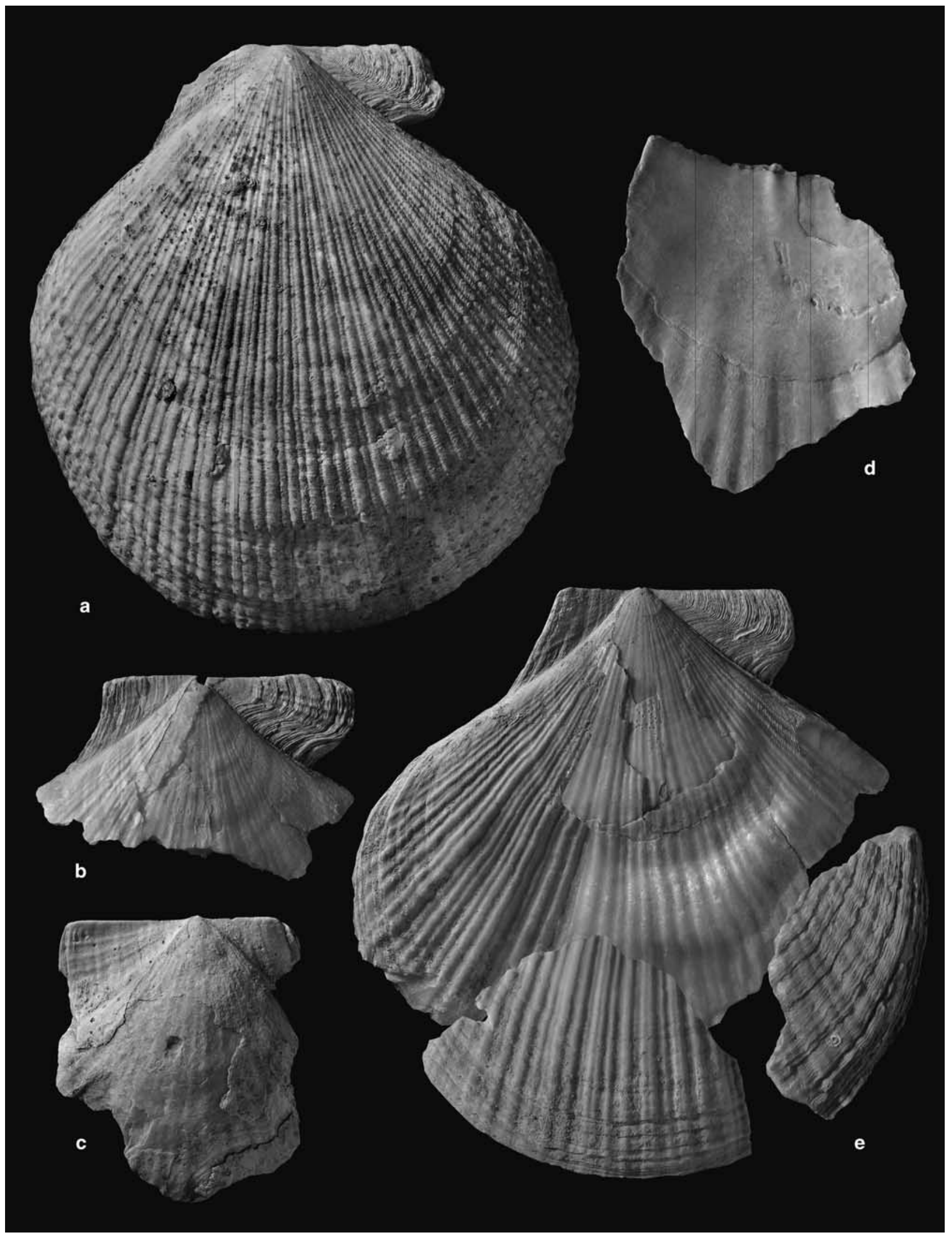


Table I. Means of selected parameters of Austrochlamys anderssoni from Brandy Bay and Cockburn Island (partly from Jonkers 2003), with their respective standard errors. Number of observations in parentheses. VH, OL, OLA, OLP, BND in mm; UA, UAA, UAP in degrees; BT dimensionless. VH was computed using regression equations in Jonkers (2000), all other values from actual measurements and counts.

\begin{tabular}{|c|c|c|c|c|c|c|c|c|c|}
\hline & VH & OL & OLA & OLP & $\mathrm{BND}$ & UA & UAA & UAP & BT \\
\hline Brandy Bay & \pm 1.4 & \pm 1.2 & \pm 0.8 & \pm 0.4 & \pm 0.5 & \pm 1.0 & \pm 0.6 & \pm 0.7 & \pm 0.6 \\
\hline \multirow[t]{3}{*}{ Cockburn Island } & 109.2 & 46.7 & 29.4 & 19.1 & 7.5 & 105.6 & 55.3 & 51.0 & 4.7 \\
\hline & \pm 1.7 & \pm 1.7 & \pm 0.7 & \pm 0.4 & \pm 0.1 & \pm 0.5 & \pm 0.3 & \pm 0.4 & \pm 0.1 \\
\hline & (264) & (29) & (51) & (62) & (215) & (47) & (91) & $(50)$ & (186) \\
\hline
\end{tabular}

Peninsula. Pale green Cretaceous siltstone/fine sandstone pebbles derived from James Ross Island are also present. Many of the larger clasts are facetted and a few in each outcrop are striated. Fossils have only been found in the large sedimentary outlier east of Stoneley Point but are scarce and highly fragmented (Nelson et al. 2009). The field relationships strongly suggest that deposition of these sedimentary beds was coeval with their immediately overlying volcanic units, which yielded ${ }^{40} \mathrm{Ar} /{ }^{39} \mathrm{Ar}$ ages of $5.64 \pm 0.25,5.36 \pm 0.05$ and $4.74 \pm 0.03 \mathrm{Ma}$ (Smellie et al. 2008; all errors are $2 \sigma$ ).

\section{Palaeontology}

The $c .100$ collected pectinid fossils (DJ.1501.1-61, lodged in the collections of the British Antarctic Survey, Cambridge, UK) are fragmented and abraded to varying degrees, but are nonetheless clearly recognizable as belonging to a single species. Fifty-six fragments are identifiable to right or left valve type, most consisting of the dorsal part of the shell with either the complete hinge preserved or with just one of the auricles present. Right valves are dominant, only seven left valves were collected. Several specimens have encrusting bryozoa and serpulids on the outer shell margins.

Ribbing on right valves is formed by a pattern of bifurcating and intercalated ribs: primary ribs bifurcate in early ontogeny, with addition of secondary ribs between the main pairs further away from the umbo (Fig. 3). Costation in the few left valve fragments is less clear, but seems to be made up of ribs that increase in number by intercalation only. Prominent commarginal lirae are present on both rib crests and in interspaces, but are visible only near the anterior and posterior disc margins, where these have escaped abrasion (Fig. 3e).

Ribbing pattern, dimensions of hinge and auricles, width of umbonal angle, and number of functional byssal teeth (Table I) confirm that the Brandy Bay pectinids can be assigned to Austrochlamys anderssoni. This species was first collected on Cockburn Island in 1903 by J.G. Andersson (Andersson 1906), and is known from several outcrops in the James Ross Island area (Jonkers et al. 2002, Smellie et al. 2006), and also from the McMurdo Sound area of the Ross Sea (Speden 1962). It has a late Miocene to late Pliocene (c. 7 to $<3 \mathrm{Ma}$ ) age range. Austrochlamys anderssoni is a chlamydoid with a rather strongly prosocline shell (Fig. 3a; see also Jonkers 2003, fig. 27), in which the anterior (partial) umbonal angle (UAA; Fig. 4) is wider than the posterior portion of that angle (UAP), but this is not well reflected in the Brandy Bay samples, possibly due to the low number of observations (Table I).

Valve height (VH; Fig. 4) of the shells from Brandy Bay could be determined by direct measurement in one specimen only (DJ.1501.8/8a; Fig. 3e; VH $114.1 \mathrm{~mm}$ ). In another (DJ.1501.5; VH c. $125 \mathrm{~mm}$ ) VH was estimated from projection onto a specimen with known valve height (DJ.851.4 from Cockburn Island). Valve height of other specimens was computed from the length of the outer ligament (OL, $n=5)$, length of the anterior outer ligament (OLA, $n=9$ ), or length of the posterior outer ligament (OLP, $n=9$ ), using the regression equations given for $A$. anderssoni by Jonkers (2000). It appears that the majority $(64 \%, n=25)$ of identifiable valves fall within a size range of $\mathrm{VH}$ $100-110 \mathrm{~mm}$ (Fig. 5a). On Cockburn Island $86 \%$ of all valves also fall within a narrow range of $100-120 \mathrm{~mm}$ (Fig. 5b; shell material only, internal and external moulds are excluded). Mean VH in the Brandy Bay and Cockburn Island samples is also remarkably similar: $105.6 \pm 1.4 \mathrm{~mm}$ $(n=25) \quad$ and $\quad 109.2 \pm 1.7 \mathrm{~mm} \quad(n=264)$, respectively. Selective removal of most left valves and nearly all valves smaller than $100 \mathrm{~mm}$ at both Brandy Bay and on Cockburn Island, together with the disarticulated nature of the material, suggests that the assemblages were modified by a single process, i.e. the repeated freezing and thawing of a thin surface layer. On Cockburn Island articulated pairs (and small valves) have only been preserved as moulds. Only a single almost articulated pair with a collapsed left valve (DJ.851.6; VH $110.2 \mathrm{~mm}$ for right valve) was encountered among 316 shelly fossils examined (Jonkers 2003).

Valves recovered from their original matrix elsewhere demonstrate that Austrochlamys anderssoni is essentially a thin-shelled species. The sharp cut-off in lower valve height of frost-heaved shells suggests that valve thickening was narrowly delineated, principally taking place during late ontogeny. Mature specimens exhibit extensive foliated calcite re-entry, which expands ventrally from the dorsal hinge region and occupies all of the area inside the pallial 


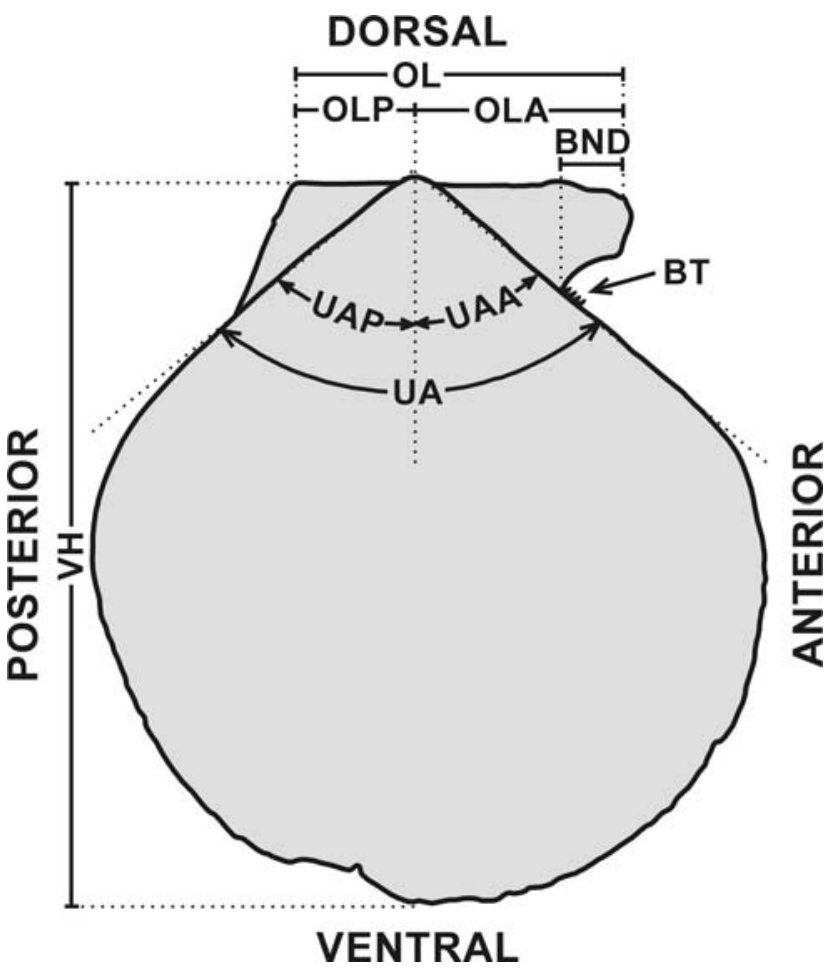

Fig. 4. Right valve of Austrochlamys anderssoni (DJ.853.1 from Cockburn Island, valve height $100.2 \mathrm{~mm}$ ) in exterior view, showing linear and angular parameters measured in Brandy Bay fossils; BT was counted. BND = depth of byssal notch, BT = number of functional byssal teeth, $\mathrm{OL}=$ length of outer ligament, OLA = length of anterior outer ligament, $\mathrm{OLP}=$ length of posterior outer ligament, $\mathrm{UA}=$ umbonal angle, $\mathrm{UAA}=$ anterior (partial) umbonal angle,

$\mathrm{UAP}=$ posterior (partial) umbonal angle, $\mathrm{VH}=$ valve height.

line (Fig. 3d). Such foliated calcite re-entry is particularly well developed in high latitude species (Waller 1991). Preferential thickening of the right valve (the valve on which the animal rests, and usually the heavier of the two: in the Recent Austrochlamys natans (Philippi, 1845) by $14 \%$ (HAJ unpublished data)) may possibly help in maintaining life position, preventing the animals from being easily overturned by currents.

The relatively narrow umbonal angle $\left(105-109^{\circ}\right)$, the low contrast in convexity between the lower (right) and the upper (left) valve (see fig. 19a in Jonkers 2003), the high auricular asymmetry (OLA/OLP $1.52 \pm 0.05, n=5$; $1.53 \pm 0.04, n=29$; in Cockburn Island shells), a byssal notch that is comparatively deep (Jonkers 2003, fig. 19b), and the high mean number of functional byssal teeth (4.7) in Austrochlamys anderssoni, are all indicative of low motility. In addition the species' close association with coarse-clastic lithofacies (conglomerate, diamictite) suggests that it may have lived attached to large clasts in water depths of $<100 \mathrm{~m}$ (Jonkers 1998a). a Brandy Bay
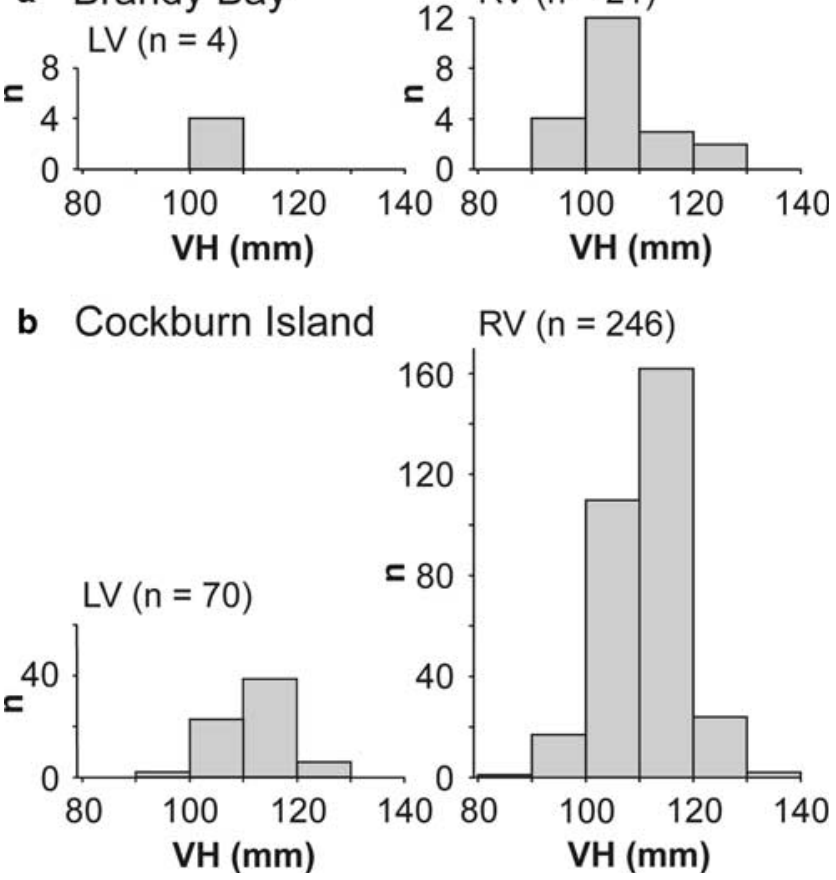

Fig. 5. Size frequency distribution of Austrochlamys anderssoni from a. Brandy Bay, and b. Cockburn Island. Valve height of shell fragments identifiable to valve type were computed with the regression equations given in Jonkers (2000). b. Adapted from Jonkers (2002). Note different scales.

Antarctic chlamydoids, including Austrochlamys anderssoni, have until recently been placed in Zygochlamys Ihering, 1907, either at subgeneric (e.g. Fleming 1957) or at generic level (Jonkers 1998a, 1998b, 2000). Because of this inclusion they have been thought of as indicators of interglacial episodes (see discussion in Jonkers 1998a). However, evidence from outcrops on northern and eastern James Ross Island, in which articulated pairs of $A$. anderssoni occur within thick-bedded glaciomarine diamictite, was interpreted by Jonkers et al. (2002) to suggest that the species is unreliable as an indicator of warmer climatic interludes. However, palaeotemperature information preserved in pectinids and bryozoans from the same stratum as discussed by Jonkers et al. (2002) clearly indicate relatively warm "interglacial" conditions and not full glacials (i.e. $\delta^{18} \mathrm{O}$ values in pectinids suggest temperatures of $c$. +2.5 to $-1.1^{\circ} \mathrm{C}$ (Williams et al. 2010), with a greater temperature range $\left(\right.$ c. $\left.5.6-7.7^{\circ} \mathrm{C}\right)$ suggested by MART (mean annual range of temperature) values in associated bryozoans (Clark et al. unpublished data; see also sedimentary evidence for "interglacial" conditions (Nelson et al. 2009). Austrochlamys anderssoni apparently favoured waters that were largely sea ice-free and it became extinct in Antarctica as sea ice extent expanded in response to climate cooling in the Late Pliocene (Williams et al. 2010).

A revision of fossil and Recent pectinids of the Southern Ocean and neighbouring regions has demonstrated that the 
scallops now included in Austrochlamys are in fact not at all closely related to Zygochlamys (sensu lato), but instead have had a long evolutionary history in Antarctica. There are currently five other known species of Austrochlamys: A. gazdzickii Jonkers, 2003, from outcrops of Oligocene rocks on King George Island, South Shetland Islands; A. marisrossensis Jonkers, 2003, from Early Miocene cored rock in the Ross Sea; Late Miocene A. heardensis (Fleming 1957), from sub-Antarctic Heard Island; A. tuftsensis (Turner 1967), from the Pliocene of Wright Valley, Victoria Land, and the Vestfold Hills, Ingrid Christensen Coast; and the extant, relict species $A$. natans, which lives in a geographically limited area off southernmost South America.

Austrochlamys has retained a number of primitive characters, such as a prosocline shell, a deep byssal notch, several modes of rib introduction in the same shell, ribs consisting of simple crenulations, commarginal lirae present in rib interspaces, and antimarginal microsculpture (Waller 1993). Shagreen microsculpture, which consists of a pattern with the appearance of a fine net, formed by the offset contacts of frilled commarginal lamellae (see Waller 1991, pl. 1, figs $7 \& 11$ ), and which first appeared in primitive representatives of tribe Chlamydini (e.g. Zygochlamys), never developed in these Antarctic scallops and Austrochlamys is therefore placed in a tribe of its own (Austrochlamydini). Representatives of the South American late Eocene to Pliocene genus Zygochlamys, which have mostly acline shells, and of the South American and New Zealand genus Psychrochlamys Jonkers, 2003, a Pliocene to Recent cold water genus with acline to strongly opisthocline shells, never occurred in Antarctica.

\section{Discussion}

Austrochlamys anderssoni is very abundant in the Cockburn Island Formation (Jonkers 1998a) and is also locally abundant within the Hobbs Glacier Formation at, for example, Pecten Spur near Cape Gage (Jonkers et al. 2002, Nelson et al. 2009). Whilst glacial strata that could be assigned to the Hobbs Glacier Formation crop out throughout northern James Ross Island (e.g. Sykes 1989, Smellie et al. 2006, Hambrey et al. 2008, Nelson et al. 2009), there are no known outcrops of the Cockburn Island Formation other than on Cockburn Island itself. When the Brandy Bay bivalves are compared with those from Cockburn Island, it is apparent that they are very similar in terms of both size and overall shell morphology, although the size distribution may be a function of the periglacial processes that have reworked the bivalves both at Brandy Bay and on Cockburn Island (Jonkers 1998a). Based upon the abundance of bivalves, it is interpreted that they have been frost-heaved from a localized occurrence of late Neogene sediment originally deposited in the Brandy Bay area. It is possible that the fossils were derived from either the Cockburn Island or Hobbs Glacier formations, or their equivalents. In an attempt to try to resolve from which formation they were derived, two specimens (DJ.1501.8 and DJ.1501.11) were selected for $\mathrm{Sr}$ isotope analysis following the methodology presented in Dingle et al. (1997) and McArthur et al. (2000). These specimens gave ${ }^{87} \mathrm{Sr} /{ }^{86} \mathrm{Sr}$ ratios of $0.709051 \pm 0.000015$ and $0.709049 \pm$ 0.000015 , respectively. The mean of $0.709050 \pm 0.000011$ $(n=2)$ is statistically indistinguishable from that of $0.709047 \pm 0.000007(n=9)$ for samples of Austrochlamys from the Cockburn Island Formation on Cockburn Island (Dingle et al. 1997; reporting uncertainty as $2 \sigma$ of the mean, rather than $2 \mathrm{SD}$ of the data, as given by those authors). In contrast, both these mean values are distinctly different from ${ }^{87} \mathrm{Sr} /{ }^{86} \mathrm{Sr}$ ratios for fossils from the Hobbs Glacier Formation, except for a single deposit at Förster Cliffs (probable depositional age $2.5 \mathrm{Ma}$, Smellie et al. 2008) that is characterized by reworked fossils (Dingle et al. 1997, Dingle \& Lavelle 1998, McArthur et al. 2006, Smellie et al. 2006, Nelson et al. 2009). Using the most recent Sr-isotope calibration curve for the interval, which includes new data for the Pliocene type-sections on Sicily (McArthur \& Howarth 2004, McArthur et al. 2006) the ratio $0.709050 \pm 0.000011$ equates to a numerical age of 4.33 $+0.6 /-1.3$ Ma. The Brandy Bay deposit almost certainly overlies Cretaceous sediments, rather than being interbedded with volcanic strata. Outcrops of the Hobbs Glacier Formation that directly overlie Cretaceous strata are distinguished by conspicuous Peninsula-derived erratics, which are absent in the Brandy Bay outcrop. Given this observation, and the comparison in overall shell size and preservation, and similar $\mathrm{Sr}$ isotope composition, it is more probable that the bivalves were derived from a unit equivalent to the Cockburn Island Formation rather than from the Hobbs Glacier Formation. This would suggest that the Cockburn Island Formation may be more geographically widespread than previously known. The low-gradient surface the bivalves are resting upon may indeed, reflect a marine cut platform (cf. Bibby 1965, Strelin \& Malagnino 1992) and thus conceivably is a very old feature (early Pliocene). The limited abrasion and their localized concentration is indicative that the bivalves have undergone minimal lateral reworking within the active layer, but these fossils are clearly no longer in their original stratigraphical context and they reflect reworking as a result of periglacial processes.

\section{Acknowledgements}

Fieldwork and $\mathrm{Sr}$ isotope analysis were funded through NERC-AFI research grant GR3/AFI2/38. Fieldwork would not have been possible without logistic support from HMS Endurance and Crispin Day. M.F. Thirlwall is thanked for access to mass spectrometric facilities at UCL for $\mathrm{Sr}$ isotopic analysis. We are grateful to A.G. Beu and T.R. Waller for their reviews; Alan Vaughan for his 
editorial comments and DP acknowledges the patience and perseverance of his co-authors for the time that this manuscript took to see the light of day!

\section{References}

Andersson, J.G. 1906. On the geology of Graham Land. Bulletin of the Geological Institution of the University of Uppsala, 7, 19-71.

BiBBy, J.S. 1965. Some observations on sea-level changes in the James Ross Island group. British Antarctic Survey Bulletin, No. 6, $67-75$.

Bü̈rck, S., Olsson, S., Ellis-Evans, C., HåKansson, H., Humlum, O. \& LiRIO, J.M. 1996. Late Holocene palaeoclimatic records from lake sediments on James Ross Island, Antarctica. Palaeogeography, Palaeoclimatology, Palaeoecology, 121, 195-220.

Dingle, R.V. \& Lavelle, M. 1998. Antarctic Peninsular cryosphere: Early Oligocene (c. $30 \mathrm{Ma}$ ) initiation and a revised glacial chronology. Journal of the Geological Society, 155, 433-437.

Dingle, R.V., McArthur, J.M. \& VRoon, P. 1997. Oligocene and Pliocene interglacial events in the Antarctic Peninsula dated using strontium isotope stratigraphy. Journal of the Geological Society, London, 154, 257-264.

Fleming, C.A. 1957. A new species of fossil Chlamys from the Drygalski Agglomerate of Heard Island, Indian Ocean. Journal of the Geological Society of Australia, 4, 13-19.

Hambrey, M.J., Smellie, J.L., Nelson, A.E. \& Johnson, J.S. 2008. Late Cenozoic glacier-volcano interaction on James Ross Island and adjacent areas, Antarctic Peninsula region. Geological Society of America Bulletin, 120, 709-731.

Howarth, R.J. \& McArthuR, J.M. 1997. Statistics for strontium isotope stratigraphy: a robust LOWESS fit to the marine strontium isotope curve for the period 0 to $206 \mathrm{Ma}$, with look-up table for the derivation of numerical age. Journal of Geology, 105, 441-456.

InESON, J.R. 1989. Coarse-grained submarine fan and slope apron deposits in a Cretaceous back-arc basin, Antarctica. Sedimentology, 36, 793-819.

Jonkers, H.A. 1998a. The Cockburn Island Formation; Late Pliocene interglacial sedimentation in the James Ross Basin, northern Antarctic Peninsula. Newsletters on Stratigraphy, 36, 63-76.

JoNKERS, H.A. 1998b. Stratigraphy of Antarctic late Cenozoic pectinidbearing deposits. Antarctic Science, 10, 161-170.

Jonkers, H.A. 2000. Gastropod predation patterns in Pliocene and Recent pectinid bivalves from Antarctica and New Zealand. New Zealand Journal of Geology and Geophysics, 43, 247-254.

Jonkers, H.A. 2003. Late Cenozoic-Recent Pectinidae (Mollusca: Bivalvia) of the Southern Ocean and neighbouring regions. Monographs of Marine Mollusca, 5, 1-125.

Jonkers, H.A. \& Kelley, S.P. 1998. A reassessment of the age of the Cockburn Island Formation, northern Antarctic Peninsula, and its palaeoclimatic implications. Journal of the Geological Society, London, 155, 737-740.

Jonkers, H.A., Lirio, J.M., del Valle, R.A. \& Kelley, S.P. 2002. Age and environment of Miocene-Pliocene glaciomarine deposits, James Ross Island, Antarctica. Geological Magazine, 139, 577-594.

LundQvist, J., LilliesKöld, M. \& Östmark, K. 1995. Glacial and periglacial deposits of the Tumbledown Cliffs area, James Ross Island, West Antarctica. Geomorphology, 11, 205-214.

McArthur, J.M. \& Howarth, R.J. 2004. Sr isotope stratigraphy. In Gradstein, F., OGG, J. \& Smith, A.G., eds. A geological timescale 2004. Cambridge: Cambridge University Press, 96-105.

McArthur, J.M., Crame, J.A. \& Thirlwall, M. 2000. Definition of Late Cretaceous stage boundaries in Antarctica using strontium isotope stratigraphy. Journal of Geology, 108, 623-640.
McArthur, J.M., Rio, D., Massari, F., Castradori, D., Bailey, T.R., Thirlwall, M. \& Houghton, S. 2006. A revised Pliocene record for marine ${ }^{87} \mathrm{Sr} /{ }^{86} \mathrm{Sr}$ used to date an interglacial event recorded in the Cockburn Island Formation, Antarctic Peninsula. Palaeogeography, Palaeoclimatology, Palaeoecology, 242, 126-136.

Nelson, A.E., Smellie, J.L., Williams, M. \& Zalasiewicz, J. 2008. Late Miocene marine trace fossils from James Ross Island. Antarctic Science, 20, 591-592.

Nelson, A.E., Smellie, J.L., Hambrey, M.J., Willaims, M., Vautravers, M., Salzmann, U., McArthur, J.M. \& Regelous, M. 2009. Neogene glacigenic debris flows on James Ross Island, northern Antarctic Peninsula, and their implications for regional climate history. Quaternary Science Reviews, 28, 3138-3160.

PIRRIE, D. 1991. Controls on the petrographic evolution of an active margin sedimentary sequence: the Larsen Basin, Antarctica. In MorTon, A.C., Todd, S.P. \& Haughton, P.D.W., eds. Developments in sedimentary provenance studies. Special Publication of the Geological Society of London, 57, 231-249.

Pirrie, D., Crame, J.A., Riding, J.B., Butcher, A.R. \& TAylor, P.D. 1997. Miocene glaciomarine sedimentation in the northern Antarctic Peninsula region; the Hobbs Glacier Formation, James Ross Island. Geological Magazine, 136, 745-762.

SKILLING, I.P. 2002. Basaltic pahoehoe lava-fed deltas: large-scale characteristics, clast generation, emplacement processes and environmental discrimination. In Smellie, J.L. \& Chapman, M.G., eds. Volcano-ice interaction on Earth and Mars. Geological Society of London, Special Publications, 202, 91-113.

Smellie, J.L. 2006. The relative importance of supraglacial versus subglacial meltwater escape in basaltic subglacial tuya eruptions: an important unresolved conundrum. Earth Science Reviews, 74, 241-268.

Smellie, J.L., McArthur, J.M., McIntosh, W.C. \& Esser, R. 2006. Late Neogene interglacial events in the James Ross Island region, northern Antarctic Peninsula, dated by $\mathrm{Ar} / \mathrm{Ar}$ and Sr-isotope stratigraphy. Palaeogeography, Palaeoclimatology, Palaeoecology, 242, 169-187.

Smellie, J.L., Haywood, A.M., Hillenbrand, C.-D., Lunt, D.J. \& Valdes, P.J. 2009. Nature of the Antarctic Peninsula Ice Sheet during the Pliocene: geological evidence and modelling results compared. Earth Science Reviews, 94, 79-94.

Smeldie, J.L., Johnson, J.S., McIntosh, W.C., Esser, R., Gudmundsson, M.T., HAMBrey, M.J. \& VAN WyK DE VRIES, B. 2008. Six million years of glacial history recorded in volcanic lithofacies of the James Ross Island Volcanic Group, Antarctic Peninsula. Palaeogeography, Palaeoclimatology, Palaeoecology, 260, 122-148.

SPeden, I.G. 1962. Fossiliferous Quaternary deposits in the McMurdo Sound region, Antarctica. New Zealand Journal of Geology and Geophysics, 5, 746-777.

Strelin, J. \& Malagnino, E.C. 1992. Geomorfologia de la isla James Ross. In Rinaldi, C.A., ed. Geologia de la isla James Ross. Buenos Aires: Instituto Antartico Argentino, 7-36.

Sykes, M.A. 1989. The petrology and tectonic significance of the James Ross Island Volcanic Group, Antarctica. PhD thesis, University of Nottingham, 218 pp. [Unpublished.]

WALLER, T.R. 1991. Evolutionary relationships among commercial scallops (Mollusca: Bivalvia: Pectinidae). In Shumway, S.E., ed. Scallops: biology, ecology and aquaculture. Developments in Aquaculture and Fisheries Science, 21, Amsterdam: Elsevier, 1-73.

WALLER, T.R. 1993. The evolution of "Chlamys" (Mollusca: Bivalvia: Pectinidae) in the tropical western Atlantic and eastern Pacific. American Malacological Bulletin, 10, 195-249.

Williams, M., Nelson, A.E., Smellie, J.L., Leng, M.J., Johnson, A.L.A., Jarram, D.R., Haywood, A.M., Peck, V.L., Zalsiewicz, J., Bennett, C. \& SCHÖNE, B.R. 2010. Sea ice extent and seasonality for the Early Pliocene northern Weddell Sea. Palaeogeography, Palaeoclimatology, Palaeoecology, 292, 306-318. 